\title{
Terrorism-Radicalism Doctrine on Social Media In Indonesia
}

\author{
Andean Bonar Sitinjak \\ \{jonhutagalung@ hotmail.com\} \\ Doctor of Law, Universitas Jayabaya, Jakarta, Indonesia
}

\begin{abstract}
The use of social media has brought some negative impacts including loss of privacy, decreased information quality, spread of hoaxes, and the rise of radical groups online. Supporters of radical groups or extremists speak up their belief on social media which can affect the public, even they recruit their members online. This descriptive research was done using a normative juridical method to analyze primary and secondary data. Data were collected through observation, document and literature study using qualitative data analysis which stages were data reduction, data presentation and conclusion drawing. The results showed that social media which allow users to share usergenerated content were often misused by terrorist networks as a powerful tool to support their movement and recruit new members as evidenced by terror cases in which terrorists made use of information technology through which they influenced and spreader the radicalization. The internet plays a bigger role in the radicalization process than any religious institution. Terrorist networks use violent terrorist campaigns as propaganda to reach operational level tactics at global and local levels.
\end{abstract}

Keywords: Social Media; radicalism, Terrorism, Internet

\section{Introduction}

The era of social media began 29 years ago, with Bruce and Susan Abelson building a social networking site called "Open Diary," with the aim of uniting online diary writers in one community [1]. With the increasing prevalence of high-speed Internet access, the concept's popularity has increased, leading to the creation of social networking sites such as MySpace (in 2003) and Facebook (in 2004). This is what gave rise to the term "social media." The earliest form of social media was a "Blog" [2], which was a website with a personal page and had many variations. A blog is actually a digital form of a personal diary that describes the life of an author and is maintained by one person, yet providing interactions with other people (blog visitors) through the comments column.

However, in the current era, the use of social media and social networks has the potential to cause new conflicts [3]. The rapid development of technology makes social media and social network users use it in the wrong way. For example, news that is not necessarily true can be disseminated very quickly, so that the police response is a little late because the incorrect information has spread widely within the community. In addition, abuse in using social media is utilized to spread hatred against the government or a state institution. This will also have an impact on the life of society and the state. Social media and social networks have flowed according to their users, it is no longer intended as positive things. Even the current era of social 
media and social networking has been used as a media for promoting a product and service by companies and product marketing experts.

In Indonesia, terrorism cases have been occurring since the Bali Bombings on October 12, 2002, continued by the Istiqlal Bombings on April 19, 1999, the Christmas Eve Bombings on December 24, 2000, and the Bombings on the Jakarta Stock Exchange in September 2000. Throughout 2018, there were also a number of acts of terrorism, that is, on May 8, 2018 a riot in the detention cell of Mako Brimob (National Polices Mobile Brigade) in Depok, where a terrorist prisoner took police officers as a hostage, and one terrorist prisoner died; May 13, 2018 suicide bombings were carried out at three churches in Surabaya, Rusunawa (flat) in Wonocolo, and Sidoarjo; May 14, 2018 suicide bombings were also carried out at the Surabaya Police Headquarters; and May 16, 2018, an attack was carried out on the Riau Police Headquarters [4].

The potential of social media has prompted optimistic statements about digital empowerment and the renewal of the public sphere. Therefore, people who use social media can increase information exchange, engagement, change their political participation, and facilitate journalism transparency. However, the negative sides of using social media include loss of privacy, declining quality of information, the proliferation of untruths ('fake news'), and the rise of online radicals [5].

According to Malinick, Tindall, and Diani [6] , there are many different opinion about how radicals can be integrated (or fail to be integrated) into framing discourse and news. According to them, some media choose their contents based on the dual purpose of maximizing profit and gaining attention from market share by covering controversial or sensational issues. Therefore, the radicals think of using extreme and dramatic ways so that their information can enter the news in every national media. In addition, crucial messages are simplified to facilitate communication and transmission [7].

In Indonesia, the pattern of radicalism is very closely related to social media, as stated by the Head of the National Counterterrorism Agency (BNPT) Komjen (Police Commissioner General) Suhardi Alius [8] that it is easy for radical understanding to spread in society. This is based on the results of BNPT survey where one of the causes of the spread of radicalism is the low level of religious understanding. The BNPT survey shows that the religious activities of Indonesians are categorized as the high one with a score of 77.73 . However, the religious knowledge of the community is relatively low, that is 25.82 . The survey shows that respondents who search for religious content through social media have a high category of 61.23 . This society is vulnerable to being exposed to negative information, not only radicalism. On the other hand, there is also less socialization, increasing suspicion of others, rapidly growing hostility and social media is always used.

The form of protection from the Indonesian government in enforcing laws related to the spread of terrorism is by creating appropriate legal products. One of the forms of a legal product is by issuing Government Regulation in Lieu of Law (PERPU) Number 1 of 2002 concerning the Eradication of Criminal Acts of Terrorism and Perpu Number 2 of 2002 concerning the Enforcement of Government Regulation in Lieu of Law of the Republic of Indonesia. Then it was updated with Law no. 5 of 2018 concerning amendments to Law no. 15 of 2003 concerning the stipulation of Government Regulation in Lieu of Law Number 1 of 2002 concerning the Eradication of Criminal Acts of Terrorism into Law. Then in 2010 the government issued Presidential Decree No. 46 of 2010 concerning the establishment of the National CounterTerrorism Agency (BNPT) as a development of the Coordination Desk for Combating Terrorism (DKPT) which was formed in 2002.

This anti-terrorism law is needed because it is included in an extraordinary crime, so law enforcement in Indonesia requires extraordinary measures. The anti-terrorism law has regulated 
the material and formal aspects, meaning that it is a lex specialis from the Criminal Code and the Code of Criminal Procedure. The public will find comfort in surfing on the internet that has been well maintained. The fact is that freedom of expression is guaranteed by both the constitution and the law. However, it is important to be wise in using social media and carrying out the truth or valid information that will be shared with others before it becomes massive public consumption. As long as it doesn't violate the others' rights, behave badly, or attack others with slander, social media can be used comfortably.

This negative side of freedom creates momentum or opportunity for adherents of radical or extremist ideologies who exercise their right to express their opinion on social media by spreading information that can influence the public, to recruiting people to follow their beliefs. Terrorism activities have the aim of making other people feel afraid so that it can attract the attention of people, groups or a nation. Usually acts of terror are used when there is no other way to carry out their will. Terrorism is not directed at the opponent, but acts of terror are carried out anywhere and against anyone. In particular, the intention conveyed by the terrorists is that these acts of terror receive special attention as psy-wars [9].

\section{Research Methods}

The method used in this study is a normative juridical method with a descriptive type of research. The data used were primary and secondary data. Data were collected by using observation, document and literature study with qualitative data analysis with stages of data reduction, data presentation and conclusion drawing.

\section{Results and Discussion}

Along with the development of the digital world, the internet is often considered as an effective communication tool for terrorist and its groups which provides them with relative anonymity [10], large amount of information and very cheap connections compared to other communication tools [11]. A potential benefit to them is the availability of important information on the internet such as instructions for making bombs, instructions for obtaining weapons of mass destruction, or guidelines for terrorist tactics. Benson asserts that this information may actually allow the actors to prepare for a terrorist attack and act completely independently [12].

However, it seems that terrorist organizations are focusing their efforts on websites mainly for self-development, not for transmitting practical knowledge, e.g. bomb construction instructions, to third parties [13]. Tsfati and Weimann analyzed some of the contents of websites of various terrorist organizations. They found that most of them avoided presenting their violent activities on their websites [14]. Instead, they usually emphasize themes such as freedom of expression or political prisoners. Significant efforts are in most cases aimed at justifying the use of force. However, this rhetorical style can be an effective tool for radicalizing website visitors, in fact, a more effective way than direct calls for terrorist attacks. Another important finding by Tsfati and Weimann is that terrorist organizations usually do not seek to mobilize website visitors directly into acts of violence. What they usually seek on the website is usually economic support [15]. However, website visitors can be indirectly pushed towards violence, e.g. call for jihad. 
Therefore, the importance of the Internet as a communication tool in the practical transfer of information or in planning terrorist attacks seems to be at least marginal. However, it is said that the internet has an important role in transferring or changing theoretical information, for example, Ideology, opinion, etc. Dissemination of information on the internet can significantly contribute to their radicalization. The purpose of terrorists using the internet is to spread the idea of jihad or ideology among Muslim communities around the world, especially in Western countries [16]. Terrorism does not always arise on the basis of religion. Fundamentalism or liberalism will not be effective in eliminating radicalism. "Radicalism is the embryo of terrorism. Radicalism is an attitude that longs for total change and is revolutionary by overturning existing values drastically through violence and extreme actions." The danger of terrorism still threatens Indonesia, even though the terrorists have been arrested. In this regard that terrorism should not only be considered in its form of terror, with a security approach, but also by resolving its ideology [17].

In Article 6 of the Law on the Eradication of the Criminal Act of Terrorism, it is clearly stated that the crime of terrorism is given the threat of severe punishment, as follows. "Everyone who deliberately uses violence or threats of violence that creates an atmosphere of terror or fear among the wide public, causes massive casualties by depriving people's freedom or property, or causing damage or destruction to vital objects Strategic, the environment or public facilities or international facilities are charged with imprisonment for a minimum of 5 (five) years and a maximum of 20 (twenty) years, life imprisonment, or the death penalty."

While Article 7, the formal offense is as follows. "Everyone who intentionally uses violence, or the threat of violence intends to create an atmosphere of terror or fear among the wide public or to cause mass casualties by depriving other people of their freedom or property, or to inflict damage or destruction on objects strategic vital objects, or the environment, or public facilities, or international facilities, shall be punished by a maximum imprisonment of life." In the article 7 of the Law on the Eradication of Criminal Acts of Terrorism, the words ".....creates an atmosphere of terror...." means that acts of terrorism are formal offenses whose formulation focuses on prohibited acts. To understand the atmosphere of terror, it is necessary to know the characteristics of terrorism.

According to Wilkinson, there are several characteristics of terrorism, including [18]:

a. Epiphenomenal terrorism (terror from below) with unplanned characteristics, occurred in the context of a fierce struggle;

b. Revolutionary terrorism (terror from below) which aims at revolution or radical change to the existing system with the characteristics of being a group phenomenon, leadership structure, ideological program, conspiracy, para-military element;

c. Sub-revolutionary terrorism (terror from below) that is politically motivated, intimidating the government to change policies or laws, political wars with rival groups, getting rid of certain officials who have the characteristics of being carried out by small groups-can also be individuals-, difficult to predict, sometimes difficult to distinguish whether it is psychopathology or crime;

d. Repressive terrorism (terror from above or state terrorism) with the motive of oppressing individuals or groups (opposition) that is not desired by the oppressors (authoritarian or totalitarian regimes) by means of liquidation using mass terror, terror apparatus, secret police, technical persecution, the spread of suspicion among the people, a medium of paranoid leaders."

Punishment for the perpetrators of terrorism in positive law in Indonesia is not only imposed on the main perpetrators such as the bombing or murder, but also for people who have 
links with the perpetrators of the crime, for example people who intentionally provide assistance or facilities to the perpetrators, or give money or financial support to perpetrators, people hiding terrorist actors or people hiding information about criminal acts of terrorism as regulated in Article 13A, which states as follows.

"Every person who has a relationship with a terrorism organization and intentionally spreading spoken words, attitude or behaviour, writing, or display with the purpose to provoke people or group or people to conduct violence or threat of violence which can cause a criminal act of terrorism shall be punished with imprisonment for a maximum of 5 (five) years."

When examining the causal relationship between terrorism crimes are mostly committed by recidivists or by people who have close relationships with previous perpetrators. Therefore, the punishment is always related to actions taken by the state based on law which of course can be a means of preventing and overcoming the crime itself. The articles of the Law on the Eradication of Criminal Acts of Terrorism contain many principles which are used as juridical aspects in the context of eradicating terrorism. Muladi said that "the principles that are highly considered in criminalizing criminal acts of terrorism are the principle of extended criminalization, the principle of non-discrimination, the principle of complementary, the principle of human rights protection and fair trial, the principle of speciale straf minima beginsel, the principal Victim and Witness protection, the principle of Legal Harmonization, the principle of balance of interests,

Terrorists who use the internet will focus specifically on turning moderate individuals into Islamic militants in Western countries. Thus, it can influence and spread the ideology of radicalization. Brandon limits three main functions of Islamic extremist websites [19]:

a. They serve as an online library of theoretical texts, covering interpretations of violence against Islam.

b. They act as a place for the preacher. On jihad websites, radical preachers can communicate with their listeners without a hitch.

c. They act as a forum for radical Islamic groups where they can exchange opinions, discuss their activities, etc.

Based on Article 6 of the Law on the Eradication of Criminal Acts of Terrorism, a person who commits a criminal act of terrorism will be threatened with a strict punishment, namely the death penalty, with an alternative to life imprisonment, and a prison sentence of 20 (twenty) years. Regarding the sanctions for actors who "participate" in the provisions of Article 9 and sanctions for actors or corporations conducting recruitment are also contained in the provisions of Article 12A and Article 12B.

Then in terms of sanctions as contained in Article 18 paragraph (2) of the Law on the Eradication of Criminal Acts of Terrorism, "The principal criminal sanction that can be imposed on corporations is only sentenced to a maximum fine of Rp. 1,000,000,000,- (one trillion rupiah)". The minimum fine is not specified in the Law on the Eradication of Criminal Acts of Terrorism so that the imposition of fines on the defendant does not reflect a sense of justice to the community because this cannot have a deterrent effect on the perpetrators. Each type of crime related to terrorism should include a maximum and minimum fine so that what the intended fine sanctions are clear, and those are some of the implementations of terrorism criminal sanctions in the Eradication of Criminal Acts of Terrorism which is still unclear so that many terrorist actors or terrorist organizations are still doing terror. 


\section{Conclusion}

The emergence of social media platforms, which support the uploading of user-generated content to easily visualize the violence of terrorism, can sensationally provide terrorist networks with powerful tools for legitimacy and efficacy in radicalization and recruitment, as the internet has done in relation to terrorists with use of information technology. Thus, it can influence and spread the ideology of radicalization. The Internet plays a big role in the radicalization process, that is actually bigger than religious institutions. Terrorist networks use terrorist campaigns of violence as propaganda by action or propaganda by violence to achieve operational-level tactics at global and local levels.

\section{References}

[1] Agafonov, Konstantin, Tadas Limba1, Tomas Pleta2, And Martynas Damkus, 'Cyber Security Management Model For Critical Infrastructure Cyber Security Management View Project The International Journal Entrepreneurship And Sustainability Issues Cyber Security Management Model For Critical Infrastructure', Article In Journal Of Entrepreneurship And Sustainability Issues, 4.4 (2017)

[2] Alfons, Matius, 'BNPT: Cari Konten Agama Lewat Medsos Rawan Terpapar Radikalisme', Detiknews <Https://News.Detik.Com/Berita/D-4323079/Bnpt-Cari-Konten-Agama-Lewat-MedsosRawan-Terpapar-Radikalisme>

[3] Benson, David C., 'Why The Internet Is Not Increasing Terrorism', Security Studies, 23.2 (2014) <Https://Doi.Org/10.1080/09636412.2014.905353>

[4] Brandon, James, Virtual Caliphate Islamic Extremists And Their Website (London: Centre For Social Cohesion, 2008)

[5] Firmansyah, Hery, 'Upaya Penanggulangan Tindak Pidana Terorisme Di Indonesia', Mimbar Hukum - Fakultas Hukum Universitas Gadjah Mada, 23.2 (2011) <Https://Doi.Org/10.22146/Jmh.16193>

[6] Fitriani, Alif Satria, Pricilia Putri Nirmalasari, And Rebekha Adriana, 'The Current State Of Terrorism In Indonesia - Vulnerable Groups, Networks, And Responses', Centre For Strategic And International Studies, 2018

[7] De Graaf, Gjalt, And Albert Meijer, 'Social Media And Value Conflicts: An Explorative Study Of The Dutch Police', Public Administration Review, $79.1 \quad$ (2019) <Https://Doi.Org/10.1111/Puar.12914>

[8] Hilkevics, Sergejs, And Aleksejs Hilkevics, 'The International Journal Entrepreneurship And Sustainability Issues The Comparative Analysis Of Technology Transfer Models *', The International Journal Of Entrepreneurship And Sustainability Issues, 4.4 (2017)

[9] 'Infografis: Aksi Teror Sepanjang 2018.', CNN Indonesia, 2018 <Https://Www.Cnnindonesia.Com/Nasional/20181218192041-15-354686/Infografis-Aksi-TerorSepanjang-2018>

[10] Kaplan, Andreas, And Michael Haenlein, 'Rulers Of The World, Unite! The Challenges And Opportunities Of Artificial Intelligence', Business Horizons, 2019 <Https://Doi.Org/10.1016/J.Bushor.2019.09.003>

[11] Lim, Merlyna, 'Freedom To Hate: Social Media, Algorithmic Enclaves, And The Rise Of Tribal Nationalism In Indonesia', Critical Asian Studies, $49.3 \quad$ (2017) <Https://Doi.Org/10.1080/14672715.2017.1341188>

[12] Loebby Loqman, Analisis Hukum Dan Perundang-Undangan Kejahatan Terhadap Keamanan Negara Di Indonesian (Jakarta: Universitas Indonesia, 1990)

[13] Malinick, Todd E., D. B. Tindall, And Mario Diani, 'Network Centrality And Social Movement Media Coverage: A Two-Mode Network Analytic Approach', Social Networks, 35.2 (2013) <Https://Doi.Org/10.1016/J.Socnet.2011.10.005> 
[14] O'Hara, Kieron, And David Stevens, 'Echo Chambers And Online Radicalism: Assessing The Internet's Complicity In Violent Extremism', Policy And Internet, 7.4 (2015) $<$ Https://Doi.Org/10.1002/Poi3.88>

[15] Rudner, Martin, “"Electronic Jihad”: The Internet As Al Qaeda’s Catalyst For Global Terror', Studies In Conflict And Terrorism, 40.1 (2017) <Https://Doi.Org/10.1080/1057610X.2016.1157403>

[16] Tsfati, Yariv, And Gabriel Weimann, 'WWW.Terrorism.Com: Terror On The Internet', Studies In Conflict And Terrorism, 25.5 (2002) <Https://Doi.Org/10.1080/10576100290101214> 